入院を要した反復性鼻出血症例の検討

宮本 真・中村 晶彦 - 池田 浩己

小椋学・山下 敏夫

\title{
Clinical Study of Hospitalized Patient with Recurrent Epistaxis
}

\author{
Makoto Miyamoto, Akihiko Nakamura, Hiroki Ikeda, \\ Manabu Ogura and Toshio Yamashita
}

(Kansai Medical University)

\begin{abstract}
Sixty-seven patients with epistaxis requiring hospitalization during the past nine years were analyzed statistically. Seven those of 67 patients complained of recurrent epistaxis and were comprisal of an approximately equal number the same of men and women. All patients except one were middle aged or older. Six patients were complicated by systemic diseases, especially hypertension, and were treated with medication. All cases except case 1 showed the same recurrent lesion at the bleeding point. Their treatments during hospitalization included hemostatic medication and tampon. Two cases of recurrent patients underwent brain angiography and arteriovenous malformation was found in one case. We conclude that recurrent epistaxis patients, especially those of the suspected of arteriovenous malformation need to undergo brain angiography recurrent vascular system.
\end{abstract}

Key words : epistaxis, hypertension, hospitalized patients, arteriovenous malformation

はじめに

鼻出血は日常診療において数多く出合う疾患であり, その多くは外来において簡単な圧迫や血管の焼灼などの 処置により止血でき，その後の経過も良好である. しか しながら，なかには入院治療を要する症例もあり，再出 血にて入退院を繰り返す症例も少なからずみられる.

今回著者らは難治性の鼻出血の治療経過中に脳動静脈 奇形がみつかった 1 症例を経験した. 症例を呈示すると ともに, 過去 9 年間に繰り返し入院を要した患者の検討 を行ったので，その結果を報告する．

\section{対象}

平成 4 年 1 月から平成 12 年 12 月までの 9 年間に, 当 科において 2 回以上繰り返し入院を要した難治性の反復 性鼻出血症例 7 例を対象とした. 鼻副鼻腔手術後の出血
症例と，悪性腫瘍による鼻出血症例は除外した。最初に 脳動静脈奇形による鼻出血の症例を提示する.

\section{症例}

症例 : 58 歳, 男性.

主訴：反復性鼻出血.

既往歴：高血圧（近医内服加療中）.

現病歴：平成 6 年右鼻出血を主訴近医入院加療し, 軽快退院するも, 鼻出血を繰り返していた。平成 10 年 12 月, 左鼻出血にて初めて当科入院となる. 上鼻甲介側 壁より拍動する出血を認め，ガーゼによる圧迫止血にて 2 週間ほどで退院となる. 1 年半経過した平成 12 年 6 月 28 日, 繰り返す左右の鼻出血にて再び入院となる. 右 キーゼルバッ八部位と左前篩骨動脈領域からの出血に て, 7 月 10 日内視鏡下に出血部位を電気焼灼し， 3 週間 


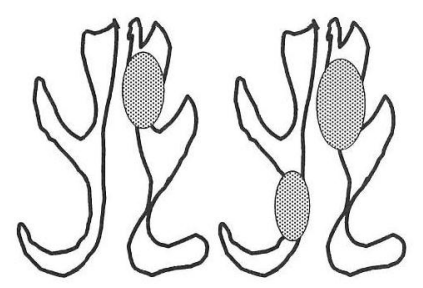

H10.12.4

圧迫
H12.7.10

内視鏡下焼灼

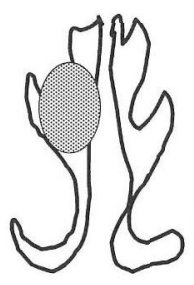

H12.8.5

内視鏡下蝶口蓋 動脈クリッピング

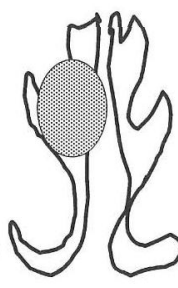

H 12.9.25

血管内 動脈塞栓
図 1 症例の鼻出血の経過

の入院で退院となる。退院後間もない 7 月 30 日, 右鼻出 血にて入院となる（図 1)。右蝶口蓋動脈領域吕らの出血 にて, 8 月 5 日内視鏡下に蝶口蓋動脈クリッピング術施 行し, 3 週間ほどで退院となる. 外来経過観察中再度右 鼻出血にて入院となり, 前回クリッピング術を施行した 蝶口蓋動脈よりの鼻出血に対し経上顎洞的顎動脈結惄術 を考慮したが, 複数部位からの繰り返す鼻出血にて血管 病変などを疑い，精查目的にて脳外科にて脳血管造影施 行した. 血管造影の結果, 左内頸動脈の正面・側面像で, 左眼動脈を経由して本来動脈相において抽出されない上 矢状静脈への造影剂の流入を認め, 動静脈奇形と診断さ れた（図 2)。また, 右外頸動脈の正面・側面像で, 動静 脈奇形の流入血管の一つである右蝶口蓋動脈に動脈瘤を 認めた（図 3)。脳 MRI では，左穊骨洞内に拡張した血 管内の血流速度が低下（flow void）したと思われる無信号 域を認めた。 また, 上矢状静脈洞・海綿静脈洞への流出
像を認め, 脳動静脈奇形が疑われた（図 4)。治療経過は, 血管造影の 1 週間後に右蝶口蓋動脈瘤に血管内動脈塞栓 術施行し, 鼻出血の止血に成功した。 以降再出血なく外 来経過観察中である.

\section{結 果}

過去 9 年間に鼻出血にて当科に入院した患者 67 例のう ち提示した症例を含む 7 例が, 反復性鼻出血にて再入院 となっている.

男女数は，男性 4 例，女性 3 例で性差は認めず，年齢 分布では 50 歳以上の中高年者に多かった（図 5)。入院 回数は, の心゙ 19 回入院で, 平均 2.7 回であった（表 1 ). 入院日数は, 男性 $10 \sim 26$ 日, 女性 $6 \sim 64$ 日で, 平均入 院日数は男性 15.5 日, 女性 28.2 日と女性が長加った (図 6)。既往歴では，6例に高血圧があり，6例とも内服 治療中であった。 1 例に肝機能障害を認めた。来院時の 血圧は，收縮期血圧は平均 $113.4 \mathrm{mmHg}$ ，拡張期血圧は $83.9 \mathrm{mmHg}$ と高血圧に対し内服でコントロールできて いた. 2 例は循環血液量減少性ショックの状態にて収縮 期血圧が $70 \mathrm{mmHg}$ と低血圧状態であった。出血点は, 提 示した 1 例を除いた 6 例においては同一部位からの繰り 返す鼻出血であった。治療は全例入院の上, 初回処置と してタンポン挿入が行われたが，タンポン挿入のみでは 止血せず，バルーンも挿入されたものが 5 回あった。 そ の後の追加治療としては内視鏡下にレーザー焼灼された ものが 4 回, 外頸動脈結紮が 1 回, 内視鏡下に蝶口蓋動 脈クリッピング術施行されたものが 1 回，血管内動脈塞

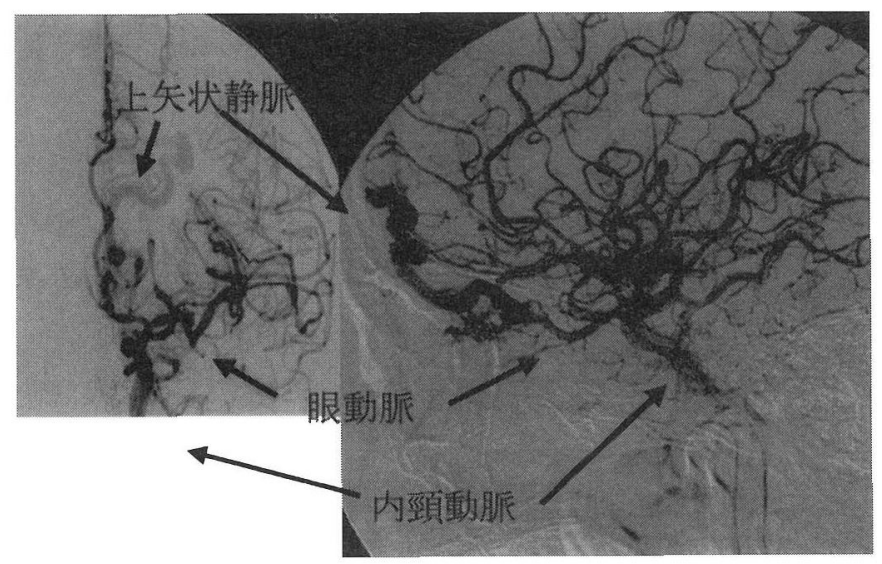

図 2 血管造影（左）

動脈相において, 左眼動脈より上矢状静脈への造影剂の流入を認める. 


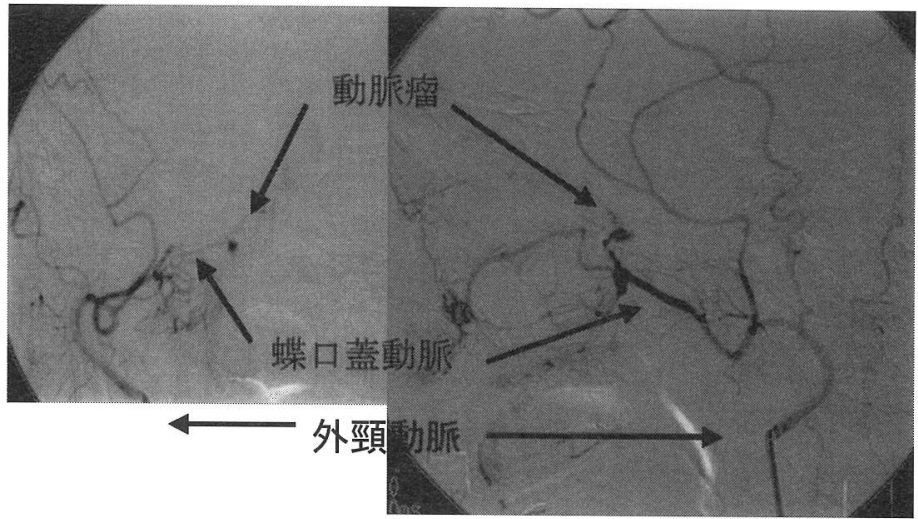

図 3 血管造影（右）

右蝶口蓋動脈に動脈瘤を認める。

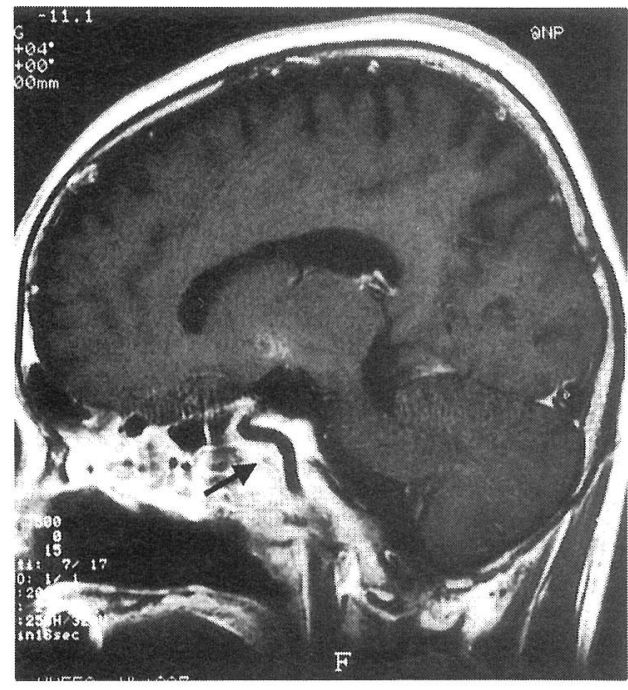

図 4 脳 MRI

左篩骨洞内に無信号領域（flow void）を認める.

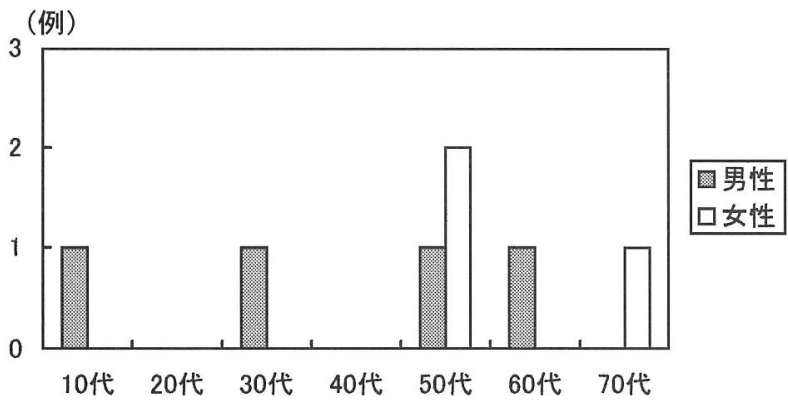

図 5 年齢分布
表 1 入院回数

\begin{tabular}{c|cccc}
\hline \hline & 2 回 & 3 回 & 4 回 & のベ回数 \\
\hline 男性 & 3 人 & 0 人 & 1 人 & 10 回 \\
女性 & 1 人 & 1 人 & 1 人 & 9 回
\end{tabular}

栓術施行されたものが 5 回あった。輸血は，男性でのべ 3 回（3/10），女性でのべ 5 回（5/9）であった。

\section{考 察}

当科で最近 9 年間に治療した反復性鼻出血症例の結果 を過去の文献を参考に考察した。入院を要した 67 例の鼻 出血症例中反復性鼻出血症例（2 回以上入院）は 7 例で, その割合は $10.4 \%$ であった。男女差に関しては，他の報 告1) 3) にあるように男性に多いということはなかった。 年齢分布に関しては，鼻骨骨折による鼻出血の 1 例を除 き,他の文献と同じように 50 歳以上の中高年者に多かっ $た^{1) \sim 3)}$. 既往歴として中高年者 6 例全例に高血圧があり， 内服加療中であった。このことは他の報告1) 3) とほぼ 一致し，高血圧の治療も必要とする症例が多かった。出 血部位に関しては，今回報告した 1 例を除き同一症例に おいて複数箇所よりの出血は認めなかった。

治療に関しては，全身的治療として全例に止血剤の投 与が行われていた。局所的治療として, 初回処置はタン ポン挿入が行われたが，タンポン㨂入による圧迫のみで は止血せず，バルーンを挿入されたものが 5 回あった。 その後の追加治療としては内視鏡下に電気メスにて焼灼 されたものが 4 回，外頸動脈結紫が 1 回，内視鏡下に蝶 口蓋動脈クリッピング術が 1 回，血管内動脈塞栓術を施 


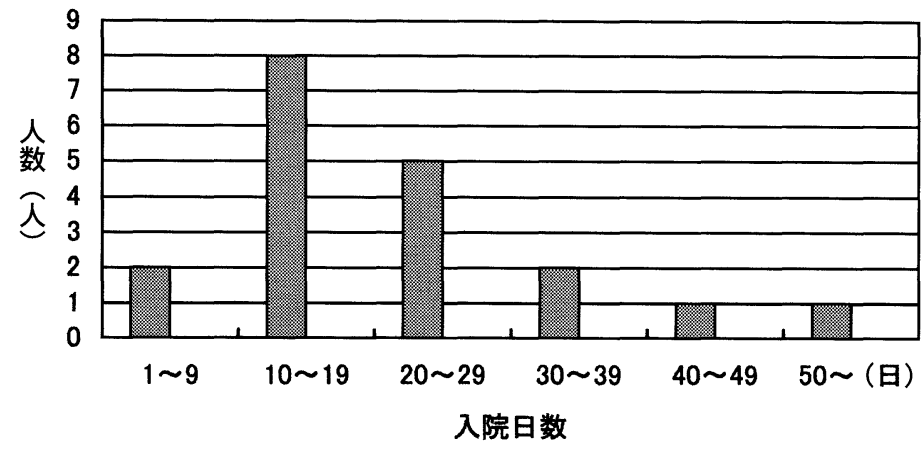

図 6 入院日数

表 2 動脈結紮術と血管内塞栓術の比較 (Cullen らの文献5)より)

\begin{tabular}{|c|c|c|}
\hline & 顎動脈結紮術 & 顎動脈塞栓術 \\
\hline 不成功率 & $11 \%$ & $24 \%$ \\
\hline 合併症 & $26 \%$ & $14 \%$ \\
\hline $\begin{array}{l}\text { 入院加療を要する } \\
\text { 重大合併症 }\end{array}$ & $\begin{array}{l}\text { 口腔上顎洞瘻, 急性 } \\
\text { 心筋梗塞, 昏睡, 狭 } \\
\text { 心症など }\end{array}$ & $\begin{array}{l}\text { 内頸動脈損傷, 片麻成䓬顔, } \\
\text { 口障害, 眼動脈塞栓な } \\
\text { ど, 禁忌あり }\end{array}$ \\
\hline
\end{tabular}

行されたものが 5 回あった. また 7 例のうち 5 例で外科 的な止血処置が施行された。 鼻出血を繰り返すような症 例では，タンポンなどの簡単な圧迫では止血困難なこと が多く，同時にバルーンも挿入されていることが多い. また追加治療として外科的に止血処置が行われているこ とが多い，治療のうち顎動脈結紮術4) と血管内動脈塞栓 術の比較（表 2）は，1998 年の Cullen ら5) の文献による と, 不成功率は塞栓術の方が高く, 結紮術の確実性を強 調していた. 重篤な合併症は結紮術では急性心筋梗塞や 昏睡などがあり, 塞栓術では内頸動脈損傷, 片麻痺, 顔 面神経麻痺や眼動脈塞栓などが起こる可能性がある，重 篤な合併症の起こる頻度は塞栓術に多い傾向を認めた。 結紮術か塞栓術を選択するかは，双方とも一長一短があ り，塞栓術を施行する設備がない施設もあり，現時点で は適応において絶対的な基準はないと考える.

全身状態に関しては鼻出血を繰り返しているため貧血 に陥っていることが多く, 7 例ののべ 19 回の入院のうち 8 回の入院時に輸血が行われ, 貧血・意識消失など循環 血液量減少性ショック状態での輸血となったものが多 かった.

鼻出血を繰り返す患者では，高血圧症を合併している 人の割合が多く，その大部分が内服加療中であり，反復
性鼻出血の誘因と考えられた. 鼻出血と高血圧との関連 性については飯沼 ${ }^{6)}$ は, 軽度の鼻出血は高血圧との関係

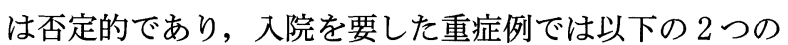
解釈より高血圧との関連が認められると述べている。一 つは高血圧は鼻出血の開始に関与するが, 重篤度（持続 時間と出血量）は血管自体の収縮性の欠如によるとの見 解と，2 つには高血圧自体は鼻出血をきたさないが，高 血圧患者の鼻出血は重篤であるので入院の頻度が高いと する見解である.

今回反復性鼻出血を主訴とすることが多い遺伝性の血 液疾患であるオスラー病 (Osler-Rendou-Weber 病) 788) は 認めなかったが，血管奇形の一つである動静脈奇形が 1 例, 肝機能障害が 1 例, 鼻骨骨折が 1 例みられた。脳動 静脈奇形は脳血管奇形の一つで，毛細血管を経由せずに 動脈と静脈の間に直接短絡を有するもので, 血圧の上昇 に対する脳血流の増加が正常脳に対し著明に大きいた め, 高血圧の既往のある本症例では特に出血しやすい背 景の一つとなったと思われる。本症例では初めの出血は 脳動静脈奇形の流入血管の一つである左篩骨洞の静脈圧 が上昇したためと考えられ，左前篩骨動脈の止血により 血流動態が変化し, 次に右蝶口蓋動脈からの出血が起 こったと考えられた. 以上より脳動静脈奇形が複数部位 からの反復性鼻出血の原因になったと考えた。

反復性鼻出血は中高年者に多く, 既往歴に高血圧を有 していた. タンポン挿入にて止血困難例が多く, 外科的 な止血処置が施行された症例も多かった。.今回のように 反復性鼻出血症例には動静脈奇形などを疑い, 血管造影 も必要であると痛感した。

\section{まとめ}

1) 平成 4 年 1 月から平成 12 年 12 月までの 9 年間に, 
当科において繰り返し入院を要した鼻出血症例は7例で, 男性 4 例, 女性 3 例, のべ 19 回, 平均 2.7 回の入院であった.

2) 中高年者に多く, 既往歴に高血圧を認め, 繰り返す 鼻出血のため外科的な止血処置が施行された症例も多 かった.

3) 今回のように繰り返す鼻出血症例には動静脈奇形な どを疑い, 血管造影が必要である.

4) 動脈結紮術と血管内動脈塞栓術の適応については今 後症例を重ね, 今後の検討としたい.

本論文の要旨は第 63 回耳鼻咽喉科臨床学会 $(2001$ 年 6 月, 沖 縄）にて口演した.

\section{参考文献}

1）日高利美, 山本栄一, 秋定 健, 他 : 入院を要した鼻出血 症例の検討. 耳鼻臨床 補 $69: 23 \sim 27,1994$.
2) 高野信也, 内村加奈子, 信貴宏治, 他 : 鼻出血症例の臨床 的検討. 耳鼻臨床 $92: 721 \sim 724,1999$.

3）増田行広, 中之坊学, 松永 毅, 他: 入院を要した鼻出血 症例の検討. 耳鼻臨床 $93: 629 \sim 634,2000$.

4) 菊池泰久：顎動脈の走行と顎動脈結禁. JOHNS $2: 1069$ 1076, 1986.

5) Cullen MM and Tami TA : Comparison of internal maxillary artery ligation versus embolization for refractory posterior epistaxis. Otolaryngol Head Neck Surg 118:636 642, 1998.

6) 飯沼壽孝: 血管異常と鼻出血. JOHNS 9:974 977, 1993.

7）濱田幸雄: オスラー病による鼻出血の 5 症例. 耳展 $40: 324$ $\sim 328,1997$.

8）市村恵一:鼻出血の鑑別診断. JOHNS 16:1607〜 1610, 2000.
原稿受付：平成14年 3 月 20 日

原稿採択：平成14年 5 月 1 日

別刷請求先 : 宮本 真

テ570-8507 守口市文園町10-15

関西医科大学耳鼻咽喉科学教室 